\title{
Collaborative Platforms for Supply Chain Integration:Trajectory, Assimilation of Platforms and Results
}

\author{
Claudia Aparecida de Mattos', Fernando José Barbin Laurindo²
}

\begin{abstract}
The transparency provided by information technology (IT) allows companies to reposition themselves in the production chain and dynamically collaborate with other companies for the purpose of optimizing their business. Thus, based on this context, this study aims to analyze the trajectory of the use of collaborative platforms to integrate supply chains based on two cases depicting different aspects of implementing supply chain collaboration practices. According to examination of these cases, interesting lessons are derived regarding the suitability and criticality of the technological approach used to support collaboration, especially regarding the use of a centralized web platform. This study provides insights for managers related to using collaborative tools and reinforcing routes established for practices when seeking to improve integrative capability.
\end{abstract}

Keywords: supply chain management; collaboration; web platform; assimilation.

'Production Engineering Dept., FEl University, São Paulo, SP, Brazil. e-mail: cmattos@fei.edu.br

2Production Engineering Dept., University of São Paulo, São Paulo, SP, Brazil. e-mail: fjblau@usp.br

ISSN: 07 I8-2724. (http://www.jotmi.org)

Journal of Technology Management \& Innovation @ Universidad Alberto Hurtado, Facultad de Economía y Negocios. 


\section{Introduction}

Collaboration enabled by information technology (IT) has been identified as an essential factor for facilitating the flow of information. Cassivi et al. (2008) indicated that in a supply chain context, e-collaboration facilitates coordination of various decisions and activities beyond transactions among supply chain partners, both for suppliers and for customers, over the Internet and over other interorganizational information systems. Based on this context, a B2B e-marketplace provides powerful IT support to enterprises implementing Supply Chain Management (SCM).A supply chain information exchange structure based on a B2B platform shares information with all enterprises at the nodes of the supply chain and tightens their connection. The overall operational efficiency of the entire supply chain is then improved. An enterprise may introduce a B2B e-marketplace to improve operational efficiency of a supply chain, promote e-business comprehensively and change the management style of the supply chain. According to Lee (2007), information sharing within business units (internal customers/partners) and with suppliers and other strategic partners (external customers) is essential to assure the seamless execution of a supply chain plan, to enjoy the maximum execution benefits and to gain competitive advantage, but is very important to provide further insights into e-collaboration adoption decisions, as argued by Chan et al. (20/2). Based on this gap mentioned by Chan et al. (2012), the interest of this study is investigating deep relationships between collaborative platforms, information sharing and collaboration to understand the trajectory for creating assimilation platforms to support supply chain integration. The following questions were formulated as drivers of this research:

I. How can we describe the trajectory of use of a collaborative platform by companies? What about the tools available in the collaborative platform?

2. What insights are yielded by this trajectory and how can they contribute to supply chain integration?

3. What is the assimilation implication of using a collaborative platform for supply chain integration?

Thus, based on this context, this study aims to analyze the trajectory of the use of collaborative platforms to integrate supply chains based on two cases depicting different aspects of implementing supply chain collaboration practices.

The next topic aims to highlight key concepts, variables and models of this research. Thus, the next section contains a review of the concepts of platforms, collaborative platforms, information sharing and collaboration, assimilation and supply chain integration.

\section{Theoretical foundation}

Collaborating means "working together to produce something with benefits for both." Therefore, in the current competitive context, collaboration can be a way to create value and to innovate. Organizations share resources, share and exchange information and have the ability to overcome some of their weak points. Bittici et al. (2005) mention that the collaborative organization refers not only to the supply chain but also to networks and clusters, including collaboration in product development (chain design) and product support (support chain). The collaborative organization extends the concepts of chains and strategic alliances, as each organization attempts to maximize its performance. According to the author, the collaborative enterprise aims to optimize the entire system, and the gains are divided among the partner companies. Bittici et al. (2003) add that the collaborative enterprise is a knowledge-based organization that uses the capacities, competences and intellectual strengths of its partners to gain competitive advantage to maximize the performance of the global enterprise.

In this context, information technology plays an important role, enabling organizations to establish relationships to foster, together, good results and productivity. According to Tapscott \& Ticoll (2005), more sophisticated tools for collaboration and management will be available, and it will be possible to conduct more complex projects, such as, for example, the co-creation of products. Several definitions have been given to collaboration within the context of supply chain collaboration and electronic collaboration (Johnson and Whang, 2002).

Johnson and Whang (2002) define e-collaboration as "business-to-business interactions facilitated by the Internet." These interactions go beyond simple buy/sell transactions and may be better described as relationships. These include such activities as information sharing and integration, decision sharing, process sring, and resource sharing. Barratt (2004) argues that:

"collaboration is a very broad and encompassing term and when it is put in the context of the supply chain it needs yet further investigation. It is an amorphous meta-concept that has been interpreted in many different ways". 
Cassivi et al. (2008) defined e-collaboration as collaboration among a group of allied parties through the use of information and communication technologies to initiate and facilitate the sharing of resources, especially across national boundaries, to improve partners' profitability. Cassivi (2006) stated that different roles may be attributed to collaboration tools, such as facilitating access to information, which affects knowledge creation capabilities, and assisting in the design of flexible supply chains.

\section{Platform concepts}

Regarding the definition of a platform, Lindquist et al. (2008) said that there is not one unified way of describing what a platform is because researchers often have their own definitions. Simpson et al. (200I) defined a product platform to be a set of parameters, features, and components that remain constant from product to product within a given product family. Meyer, M.H. et al. (1997) defined a platform as a basic architecture composed of sub-systems or modules and the interfaces between them. Lindquist et al.'s (2008) description of platforms addresses the need for interfaces between interacting systems. Interfaces do not necessarily refer to physical interfaces; they can also refer to data exchange, heat transfer or various other factors influencing surrounding systems.

\section{Collaborative platforms, Information sharing and Collaboration}

Cassivi et al. (2000) has discussed electronic commerce and said that few people have been able to grasp the full impact of the adoption and use of these emerging communication technologies. These authors said that e-commerce refers to many different activities, such as sending a bid through an EDI (Electronic Data Interchange), an engineer exchanging technical drawings through a virtual private network and others. Based on this scenario, implementing B2B e-commerce though platforms will allow participants to share information and exchange various documents, such as contracts, CAD files, and video conferences. Thus, suppliers could receive delivery instructions in different manners, either EDI or WebEDI, via email. In fact, platforms can represent open and fast communication mechanisms, which are essential for companies entering into supply chain network activities, allowing its members to jointly forecast, develop, produce, synchronize, and deliver their products/ services to anticipate dynamic customer requirements.

According to Cheng Tian-Min (2009), collaborative e-commerce platforms link business partners, suppliers, distributors, retailers and even end-users together, mine and meet market demand, and form a dynamic alliance of enterprises. Xian and Huo (2004) mentioned that under the unified scheme, all enterprises in the supply chain develop products collaboratively via the coordination of material procurement, modular production, logistics distribution and marketing. In the same manner, Vicky Manthou et al. (2004) discussed in their research that supply chain integration in a virtual environment can be defined as the process by which suppliers, partners, and customers within a shared market space collaboratively plan, implement and manage the flow of information, services and products along the supply chain in a way that improves business operations in terms of speed, agility, real time control, or customer response. Based on this context, the rise of the Internet and the WorldWide Web, as business-to-business communication vehicles, has created a new set of integration challenges for companies that want to automate the flow of information and integrate their business processes across their extended enterprise of customers, suppliers and partners. Pramatari, K. (2007) mentioned that supply chain collaboration practices and the underlying enabling technologies have evolved, from the classical EDI approach to web-based and RFID-enabled collaboration. Thus, companies in all industries are seeking to implement customer self-service applications and striving to provide their partners and suppliers with controlled access to their internal information systems and business processes. Their incentive is to reduce cycle time and inventory levels and to better coordinate production and fulfillment operations. The successful operation of a modern networked virtual supply chain partnership mandates that every member must be able to share information with trading partners and customers in real-time, preferably without manual intervention, whenever possible. Such real-time system-to-system communication is realized by enabling disparate information systems to share data in the context of specific business processes. Chan et al. (20I2) noted that without the mediating role of information sharing and collaboration, supply chain performance would not occur. In particular, collaborative effort plays the major mediating role in achieving supply chain performance as the enabler of information sharing and the initial driver of SET-based issues.

Gunasekaran and Ngai (2004) bring this discussion to the strategic level and argue that strategic information sharing creates competitive value and furthers the strategic impact of the supply chain partnership as a whole on the industrywide structure.

A study conducted by Cassivi (2006) identified eight electronic tools used to exchange critical information among supply chain partners. These supply chain e-collaboration tools are categorized as supply chain planning (direct procurement, replenishment, shortages, delivery and tracking, design based on CAD) or supply chain execution tools (forecasting, capacity planning, business strategy). 
Sodero et al. (2013) argues that in recent years, firms have established Internet-based electronic linkages with their trading partners, and these authors discuss the results related to the ability to coordinate and synchronize shared business processes by using more complete, accurate, and timely information.

According to $\mathrm{Yu}$ et al. (2008) and Vreed and Dickson (2000), the emergence of information technology (IT) tools has offering new methods to coordinate and to conduct collaborative business processes, such as, EDI (Electronic Data Interchange), e-mail, Intranets, Extranets, video conferencing technology, and video conferencing technology working groups (workgroups), as the workflow. Thus, electronic collaboration has been realized, enabling interfaces between suppliers and customers. Online environments represent a united front for all suppliers and customers, eliminating the need for communication with dozens of them even when changes occur during the process.

$\mathrm{Li}$ et al. (2009) mentioned that the implementation of information technology (IT) for supply chain management (SCM) is becoming important in the context of an increasingly globalized and competitive economy. For these authors, IT, by providing timely, accurate, and reliable information, has greatly improved supply chain performance.

In the same manner, Carr and Smeltzer (2002) mentioned that information technology is often perceived as an important contributor to supply chain collaboration (Carr and Smeltzer, 2002), even though a handful of research initiatives have come to the opposite conclusion, i.e., that Information Technology does not, in fact, improve supply chain performance (Jayaram and Vickery, 1998).

Li,Gang etal.(2009) proposed five levels for IT implementation. Related to IT implementation, these authors defined five items to compose an IT construct: EDI, bar code usage and data capture, effective usage of computers in operations and decision-making, open standards and unique identification codes, and decision-making systems and support. For each IT construct item, these authors established five levels of analysis (these levels are detailed in Appendix A).

\section{Supply Chain Integration and Assimilation Platform}

Many authors, such as Danese and Bortolotti (2014), der Vaart and van Donk (2008), Flynn et al. (2010), Zhao et al. (20l I) and Barrat and Barrat (20I I), have argued that supply chain integration combines internal and external information-based linkages to extend visibility across the entire supply chain. Visibility can provide benefits, not only in terms of operations efficiency (e.g., Smaros et al., 2003), i.e., increased resource productivity, but also in terms of planning effectiveness.

Barrat and Oke (2007) defined supply chain visibility as:

"the extent to which actors within a supply chain have access to or share information that they consider as key or useful to their operations and that they consider will be of mutual benefit".

A number of researchers have suggested that such visibility can lead to improvements in operational performance (Mentzer, et al. (2004); Barratt, M.A., Oke,A., (2007)).As such, improvements in operational performance are considered in terms of increased sales, improvements in customer service, reduction in the levels of on-hand inventory, together with improvements in forecast accuracy and the number of quality-related issues. Some authors have found in their studies a positive relationship between integration and different measures of organizational performance (e.g., Barney 199I, Chalmeta et al. 200I, Mukhopadhyay and Kekre 2002). Didonet and Diaz (2012) reinforce the notion that effective supply chain management, which includes collaborative practices and IT integration with suppliers and clients, would enable enterprises to improve their performance in innovation.

Considering the importance of supply chain integration and information technology as an enabler, it is essential to discuss the effective IT assimilation, particularly collaborative platforms for the management of the supply chain. Based on Liu et al. (20/3), IT assimilation refers to the ability to diffuse and routinize IT applications in business processes within and across organizational boundaries, and this ability facilitates a firm's use of advanced IT applications (e.g., e-business technologies or platforms). Russell et al. (2004) mentioned this in his work on the technology diffusion theory, which has been widely used and tested but has been little used in the management of supply chains to explain why full utilization is not reached, despite several academic studies suggesting the benefits of using IT as a facilitator for the sharing of inter-organizational information and coordination of activities. 
Based on that context, platforms represent one way to support supply chain integration, but Paulraj et al. (20I2) and Zhou and Benton (2007) argue that the assimilation of platforms to support the integration of IT and interorganizational business standards in supply chains is a fairly recent phenomenon and that there are few drivers identified by research studies in this area. Varella and Buss (2013) reinforce that the integration of supply chain participants is a difficult task because of the number of players involved and that it is limited by factors such as cultural rivalries, weaknesses and deficiencies in information systems, and lack of alignment in manufacturing processes with the strategic plans of the company. Significant complexity exists because no system was originally designed to share information with other systems. In many cases, IT processes evolve in time-varying and disconnected ways, based on local and global requirements of the company, which are rarely integrated. Chung et al. (20II) discuss how the task of integration is a huge organizational effort and demonstrated linkages between ERP and SCM systems in terms of several IT factors. ERP systems were introduced for managing business resources across many functional areas within a corporation and are now being enhanced with SCM functionality.
Kaminsky (2003) mentioned that an efficient flow of information between the parts of the process to achieve integration between suppliers, manufacturers and customers is necessary and that the development of standards for communication and the interface are very important. Business integration requires the support of physical integration and application integration for easy communication and exchange of information. However, business integration, addressed since the 1980s, has yet to develop to a satisfactory level (Panetto and Molina, 2008). Childerhouse and Towill (20II), in the same way, mentioned in their study that in practice, the majority of supply chains are not well integrated.

\section{Relating collaborative platforms and integration of supply chains: proposal of a theoretical framework}

Fig. I shows the theoretical framework used in this study. This theoretical framework was composed of concepts indicated by a literature review as important to supporting the integration of supply chains. Combining collaborative platforms, information sharing, and collaboration can help with understanding of the trajectory and efforts of the integration of supply chains. It is a theoretical framework that will be used for analyzing data from the study of two cases presented in this paper.

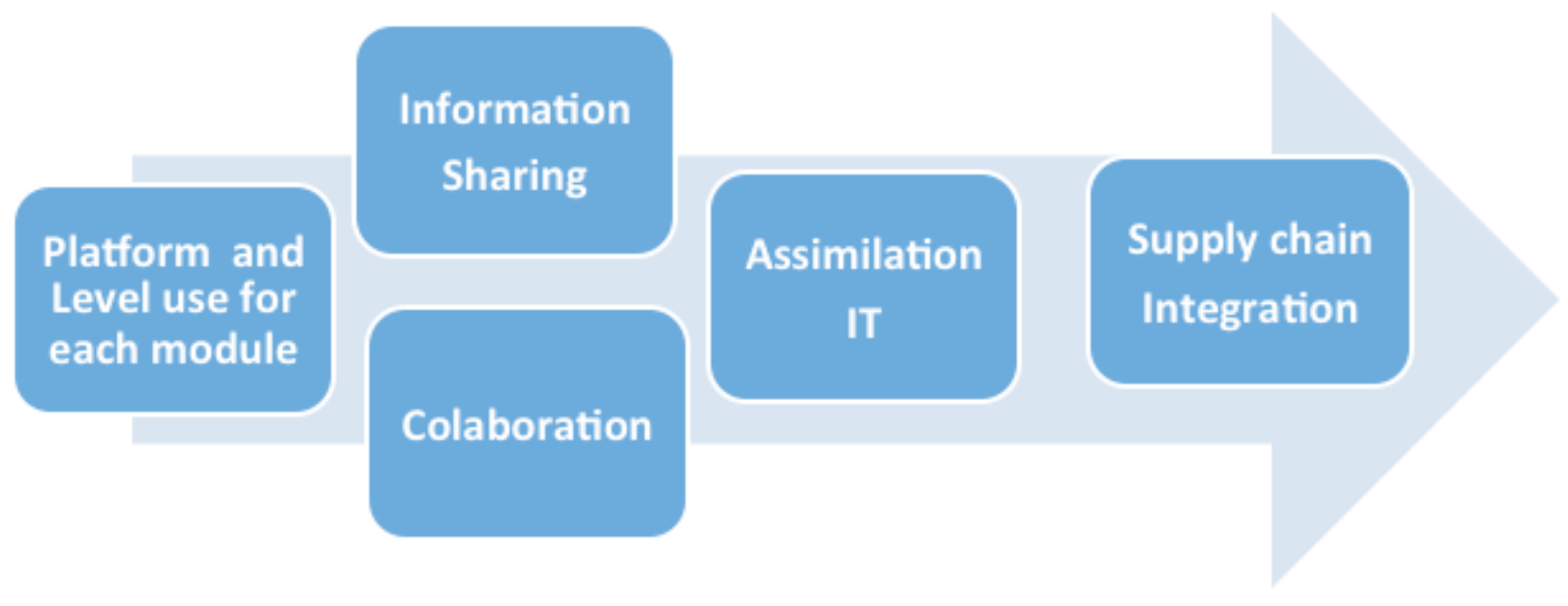

Figure I- Proposal of the theoretical framework 
Table 2 presents in more detail each variable used in this study and their items that were analyzed in the case study.

\section{Method}

To investigate the aspects of using collaborative platforms for the integration of supply chains, a qualitative research approach was adopted and developed through two case studies in companies from the manufacturing sector. According to authors such as Forza (2002), Voss et al. (2002) and Yin (2005), a case study is a valid approach when the aim is to understand a phenomenon that occurs within a context and the researcher has no control over the events. Additionally, it is a valid approach when the research seeks to answer questions such as "Why have they been made?" or "How have they been implemented?" For the present research, it is suitable as the main objective is to investigate how collaborative platforms are being used to improve supply chain integration. The two companies participating in the case studies are labeled as Company $\mathrm{X}$ and $\mathrm{Y}$.

\section{Subjects or Participants Case \# I}

Company $\mathrm{X}$ is a global company focused on the design and production of components, integrated systems and modules for the automotive industry. The company has plants and suppliers in different parts of the world (Latin America, the Americas, Asia and Europe).

\section{Case \#2}

Company $Y$ has a leading position in the technology and engines manufacturing sector. The company has plants and suppliers in different parts of the world (Latin America and the Americas). The company produces engines for trucks, agricultural machinery and generators, with approximately two hundred suppliers upstream in the supply chain.

\begin{tabular}{|c|c|c|}
\hline Variables & Items & Author references \\
\hline Platform and Level use for each module & $\begin{array}{l}\text { Technology readiness } \\
\text { Technological integration } \\
\text { IT modules and levels }\end{array}$ & $\begin{array}{l}\text { Lindquist et al. (2008), Chan et al. (20I2) } \\
\text { Li et al. (2009) }\end{array}$ \\
\hline Information Sharing & $\begin{array}{l}\text { Willingness on the part of the company } \\
\text { and partners to share information }\end{array}$ & $\begin{array}{l}\text { Wu et al. (20|4), Chan et al. (20I2), Cassivi } \\
\text { (2006) }\end{array}$ \\
\hline Collaboration & $\begin{array}{l}\text { Shares information to plan and execute the } \\
\text { supply chain (e.g., designs, plans, forecast } \\
\text { demands). } \\
\text { Supply chain partners have frequent inter- } \\
\text { action while problems occur. }\end{array}$ & Wu et al. (20I4), Cassivi (2006) \\
\hline Assimilation IT & $\begin{array}{l}\text { Company has implemented IT applications } \\
\text { in many business processes. } \\
\text { Company has implemented IT applications } \\
\text { in a large number of functional areas. } \\
\text { Company uses IT applications in manage- } \\
\text { ment to a high degree. }\end{array}$ & Liu et al. (20I3) \\
\hline Supply Chain Integration & $\begin{array}{l}\text { Visibility } \\
\text { Internal and external integration } \\
\text { Benefits as a whole } \\
\text { Creates the strategic impact of supply } \\
\text { chain partnership as a whole }\end{array}$ & $\begin{array}{l}\text { Barrat and Barrat (20I I) Flynn et al. (20I0); } \\
\text { Gunasekaran and Ngai (2004) }\end{array}$ \\
\hline
\end{tabular}

Table -2 -Variables and Items - Proposal of a theoretical framework

ISSN: 07 I8-2724. (http://www.jotmi.org) 


\section{Procedure}

To achieve the results, the study was carried out through semi-structured interviews with IT and those responsible for supply chain management. All of the interviews were recorded and transcribed, and the reports were sent back to the interviewed person to be validated. The script used as the data collection instrument was the same for both companies and was constructed to allow the identification of the most important points and the link between the theory and the practice. In addition, documents provided by the companies for this study were also analyzed.

\section{Results}

\section{Case I - Company X (Global Company) Platform and Level use for each module}

Before the present use of a collaboration portal, Company $X$ invested in an ERP system to promote internal integration, referring primarily to data and information system integration through the use of enterprise resource planning (ERP), real-time searching of inventory and operating data, and integration of activities in different functional areas. Company $X$ began to use the portal in 2002, and to date, 75 plants in different countries, with more than 1700 suppliers, are integrated into the collaborative portal of the company (Figures I and 2). Company $X$ has started with a WebEDI solution, but this platform is in continuous evolution.

During this period, the company had developed releases related to this portal. The new version included various new functions, especially for process delivery and transport data but also new processes such as the credit note for consignment, a standard process for demand management, the Pull List philosophy and the e-Reorder Process (electronic Re-Order).

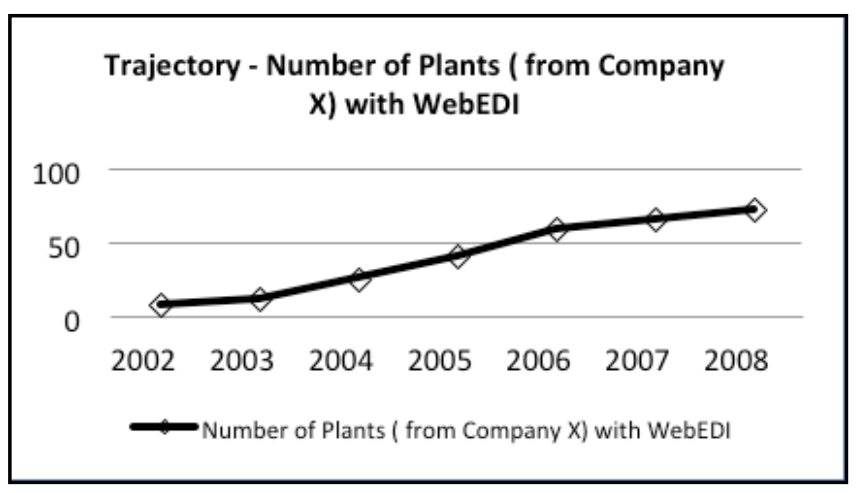

Figure I - Plants with WebEDI (case I)
Trajectory - Number of suppliers using the WebEDI platform of company $X$

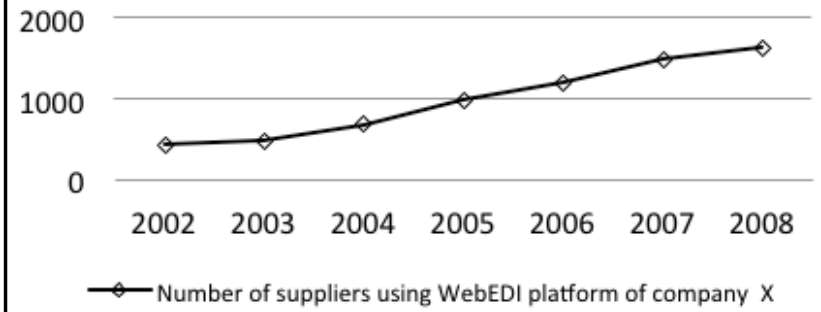

Figure I - Plants with WebEDI (case I) Figure 2 - Suppliers using the platform (case I)

\section{Information Sharing and Collaboration}

It is possible for a supplier to obtain an overview of all demands placed on a plant of Company $X$ / an unloading point. With this new function, the supplier can very easily obtain an overview of all demands in the short- and midterm, and suppliers can download options for delivery instructions, credit notes and stock movements in different formats. This action allows them to develop reports and better control. For each new feature of the portal, the corporation establishes a roll-out implementation. The job starts with the plant and subsequently extends to the suppliers of this plant.

\section{Assimilation Platform}

In 2010, company $X$ conducted a general survey of WebEDI suppliers. The results showed that the application and the service around the platform system do currently address most needs of suppliers, with a $78 \%$ general satisfaction level. The company has invested over several years to integrate all plants and suppliers into this portal. Reductions in transaction costs and gains in accuracy and agility are reported by the company, but there are ongoing efforts to achieve full integration.

According to the head of the IS Group Competence Center WebEDI from Company $X$ :

"The comprehensive coverage of the supply chain offers us a high savings potential.This applies even more so to incoming messages such as delivery notes including barcode labels and packaging. We have been able to significantly optimize our incoming goods process with the barcode labels. The quality of the data is excellent."

ISSN: 07I 8-2724. (http://www.jotmi.org) 
For Company $\mathrm{X}$, the goal of supply chain management is to improve performance through the effective use of resources and capabilities via the development of internal integration and external integration with suppliers to create a seamlessly coordinated supply chain, thus elevating interfirm competition to inter-supply chain competition. Based on this context, the impact of e-collaboration can be traced and evaluated. The company is investing in formal supplier development programs and implementing a rigorous selection process for new suppliers to apply the total quality and innovation approach to suppliers and contractors and to establish close partnerships with the most innovative and high-performing suppliers.

\section{Case \#2 - Company Y (Focal - one plant) Platform and Level use for each module}

The company operates two manufacturing plants in Brazil, but this study is limited to one plant (Company $\mathrm{Y}$ ). This company invested in a platform for managing its operations along with the production chain. The main reasons for the development of the web platform to manage the production chain were an extremely fragile execution control process (large influence of the human factor), the need for increased reliability and lower response time, the need for collaboration in the planning process, and demand volatility (volume and mix).

The functionalities of the portal are:
Company $Y$ began using the portal in 2006 and in 2010, achieved the integration of almost 200 suppliers into the portal (Figure 3). Another function available in the portal is the VMI tool (Vendor Management Inventory), which allows suppliers to monitor inventory and demand levels in the company. Before using these tools, the controls were more rudimentary (by phone and fax).

The company implemented this portal only for the Brazil plant. The related level of use depends on the functionality.

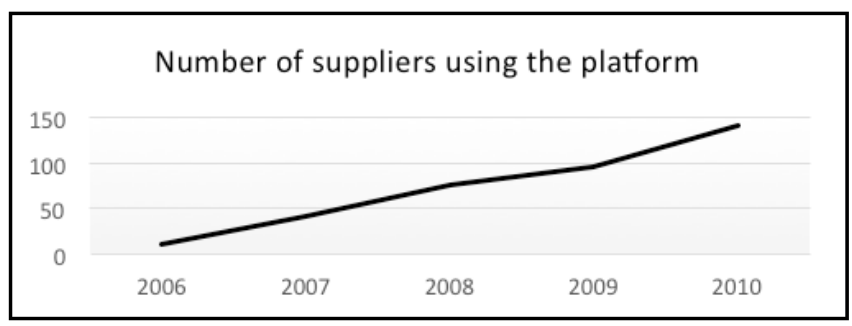

Figure 3- Suppliers using the platform (case 2)

\begin{tabular}{|l|l|}
\hline Portal's Functionalities & Description \\
\hline Schedule of supplier's deliveries & $\begin{array}{l}\text { On-screen visualization, Print of schedule; } \\
\text { Download of files in Acrobat Reader format; } \\
\text { EDI in standard Anfavea format, automatic notices by e-mail } \\
\text { for each new schedule; }\end{array}$ \\
\hline $\begin{array}{l}\text { Collaborative Planning: Schedule Ac- } \\
\text { ceptance }\end{array}$ & $\begin{array}{l}\text { Updates Purchase Orders according to the received accept- } \\
\text { ance, reduces negotiation time; }\end{array}$ \\
\hline Advance Shipment Notice (ASN) & $\begin{array}{l}\text { Supplier informs them of a shipment via: } \\
\text { Record on a WEB screen } \\
\text { Upload of an RND - (Text file in standard Anfavea format); }\end{array}$ \\
\hline Payments to Suppliers & Web control of payments to suppliers \\
\hline
\end{tabular}

Table 3 - Portal's Functionalities for the Chain Management 


\section{Information Sharing and Collaboration}

With the portal, a new management model supply was established, providing improvements in some respects, as noted below.

- Deliveries programming - was reduced to one day average time for the exchange of information; dropped by approximately 12 hours per employee per week for tasks that do not add value (phone calls, typing notes, tax, etc.).

- Departure warning - the percentage of invoices without errors (received by webEDI) increased from approximately $44 \%$ to over $70 \%$ in the first year the portal was available and is still growing.

- Inventory visibility to the client and on the road - at the supplier cockpit, the supplier base has access to situation deliveries, demands, stock in transit and stock on the client, which increases the flexibility of deliveries

- $\quad$ Performance indicators availability

- $\quad$ Failures and recovery - the portal Quality module has accelerated the reporting of failures, customer complaints and responses to providers, brought consistency to the problem analysis and disciplined deadlines for compliance with the actions (on-time response to the Quality module by suppliers is critical and has increased by more than $40 \%$ ). It also permitted the committed supplier to be established, based on the indicator of compliance with the corrective action deadlines, which is capable of failure to recover satisfactorily.

In addition to the development of the manufacturing process and delivery of suppliers, there are also technical development components: the focal company involves suppliers from the beginning of development, with the objective being to reduce the number of failures after the product launch, make the item assembly process more robust and lower costs. As it is essentially an automaker, the focal firm does not control all of the technology involved in the construction of motors using the ESI in several levels. Standardized components, such as nuts, low-resistance bolts, washers and printed media, are acquired with a low level of involvement (supplier design). The vendor receives the items of the project and is responsible for fulfilling their specifications at the lowest possible cost. Other components and engine subsystems, such as the injection system, turbines, oil and water pumps, involve the domain technology provider. In this case, the level of involvement of the provider is high (source design), and the focal company transfers overall responsibility to the supplier for the development of the item.

Recently, Company $Y$ has changed the portal and deployed a new ERP system (SAP) as a result of the need and opportunity to revitalize this tool.

\section{Discussion}

According to the examination of these cases, interesting lessons are derived regarding the suitability and criticality of the technological approach used to support collaboration, especially regarding the use of a centralized web platform. These supply chain environments continuously evolve and use electronic collaboration tools to manage and execute complex supply chain activities. With sophisticated e-commerce and collaboration tools, firms can share information and collaborate with partners to support supply chain activities. Collaboration tools are related to external integration, but, if internal integration is not ready or less than optimal for information flow, the maximum benefit for supply chain execution with external partners will also be severely compromised, in alignment with the research of Lee et al. (2007). The results indicate that the integration of supply chains has a trajectory that begins with the use of an ERP system for the company to promote some internal integration. The ERP system has represented the initial step to begin internal integration, and it is aligned to Barrat and Barrat (2007) and Chung (20I2). Both companies $(X$ and $Y$ ) have invested money and time to implement and maintain the hardware, software, protocols, and standards necessary to monitor internal information and communicate with other external parties as well. In addition, each company has invested heavily in building its supply chain management system, ERP infrastructure and other computerized systems over time.

Company $X$ offers in its portal the following: WebEDI, bar codes, decision-making systems and other tools, as mentioned before. The level depends on the type of information technology available in the portal. In this case, for WebEDI, the company can be classified as level 5. Other related modules available within the company can be classified as level $2-3$ according to $L i$ et al. (2009). When we analyzed the Modules implementation (Levels analysis), we saw that there is a journey to achieve supply chain integration that involve several variables, such as: trust, technical capacity of suppliers, social influences, communication between suppliers and organization involving many stakeholders and different communication channels resulting in a loss of communication and the need for transparency between organizations and its suppliers/ sub-contractors for a mature relationship. However, even companies $\mathrm{X}$ and $\mathrm{Y}$, with their formal supplier development programs and commitments of the entire company to open, collaborative relationships with suppliers, seem to suffer from persistent gaps between their ostensible objectives and practice due to internal organizational problems, such as cross-functional conflicts, high staff turnover, absence of communication polices, and the gap between corporatelevel policies and those of the plant. Portals from companies

ISSN: 07 I8-2724. (http://www.jotmi.org)

Journal of Technology Management \& Innovation @ Universidad Alberto Hurtado, Facultad de Economía y Negocios. 
provide visibility to the suppliers, allowing them to access the current status of stock delivered or in transit.Another point is related to the quality management of suppliers; with the portal, this can be observed more transparently in relation to targets set by the company, and a new management model can be established.

Table 4 shows the results summary related to study realized in two companies.

\section{Theoretical Implications}

The business environment has undergone profound changes in recent years, which have been considered directly related to IT. Thus, exploring the full potential and creating value through technology has been one of the great challenges facing organizations. The search for variables related to IT that impact the results has been examined by many researchers because many companies have not obtained the expected results with the adoption of IT tools. It is also true, which are the very factors that impact in getting better results with the use of IT and one of the factors associated

\begin{tabular}{|c|c|c|c|}
\hline Variables & Case I & Case 2 & Authors reference \\
\hline $\begin{array}{l}\text { Platform and Level use for } \\
\text { each modules }\end{array}$ & $\begin{array}{l}\text { The global company uses its } \\
\text { own platform and has invested } \\
\text { in ERP systems to prepare } \\
\text { the company for supply chain } \\
\text { integration. Thus, items (Tech- } \\
\text { nology readiness, Technological } \\
\text { integration and IT modules, } \\
\text { and level-related technology) } \\
\text { are aligned to theory }\end{array}$ & $\begin{array}{l}\text { The local plant developed its } \\
\text { own platform and has invest- } \\
\text { ed in ERP systems to prepare } \\
\text { the company for supply chain } \\
\text { integration. In this case, the } \\
\text { results are aligned to theory }\end{array}$ & $\begin{array}{l}\text { Lindquist et al. (2008), } \\
\text { Chan et al. (20I2), Li } \\
\text { et al. (2009), Barrat } \\
\text { and Barrat (2007) and } \\
\text { Chung (20I2) }\end{array}$ \\
\hline Information Sharing & $\begin{array}{l}\text { Willingness to share informa- } \\
\text { tion and knowledge }\end{array}$ & $\begin{array}{l}\text { There is a willingness to } \\
\text { share information, but only } \\
\text { for some types of informa- } \\
\text { tion - partial adherence to } \\
\text { theory }\end{array}$ & $\begin{array}{l}\text { Wu et al. (20|4), Chan } \\
\text { et al. (20I2), Cassivi } \\
(2006)\end{array}$ \\
\hline Collaboration & $\begin{array}{l}\text { To share information to plan } \\
\text { and to execute the supply chain } \\
\text { (e.g., designs, plans, forecast } \\
\text { demands). }\end{array}$ & $\begin{array}{l}\text { To share information to plan } \\
\text { and to execute the supply } \\
\text { chain but focus on transac- } \\
\text { tional information }\end{array}$ & $\begin{array}{l}\text { Wu et al. (20I4), Cas- } \\
\text { sivi (2006) }\end{array}$ \\
\hline Assimilation Platform & $\begin{array}{l}\text { Company has implemented IT } \\
\text { applications in many business } \\
\text { processes and is in evolution } \\
\text { In this case, results indicated an } \\
\text { assimilation platform and ability } \\
\text { aligned to the authors }\end{array}$ & $\begin{array}{l}\text { Company has implemented } \\
\text { IT applications in some busi- } \\
\text { ness processes. Results indi- } \\
\text { cated that the platform does } \\
\text { not include new applications. } \\
\text { Limited use } \\
\text { In this case, results indicated } \\
\text { a partial assimilation platform }\end{array}$ & Liu et al. (20I3) \\
\hline Supply Chain Integration & $\begin{array}{l}\text { Case I improved visibility, and, } \\
\text { for each module, there is spe- } \\
\text { cial work with suppliers }\end{array}$ & $\begin{array}{l}\text { Results indicated that with } \\
\text { the portal, a new manage- } \\
\text { ment model supply is estab- } \\
\text { lished, providing improve- } \\
\text { ments in some respects, but } \\
\text { the supply chain is not very } \\
\text { well integrated. }\end{array}$ & $\begin{array}{l}\text { Barrat and Barrat } \\
(20 I I) \text { Flynn et al. } \\
(20 I 0) \text {; Gunasekaran } \\
\text { and Ngai (2004) }\end{array}$ \\
\hline
\end{tabular}

Table 4 - Summary of the Cases - Findings based on theory

ISSN: 07 I8-2724. (http://www.jotmi.org)

Journal of Technology Management \& Innovation @ Universidad Alberto Hurtado, Facultad de Economía y Negocios. 
with the assimilation of technology. Thus, understanding the trajectory by which end users endorse and adapt to technological changes could mobilize management practices to create a work environment that is receptive to the effective use of a new information system and therefore create an opportunity to create value. Although the web can act as a major facilitator, it is only a partial answer to supply chain integration. Theoretically, implications of this research will be salient for the research fields of Information technology and supply chain management. First, we attempt to investigate the constitutive roles of information systems and collaborative platforms in particular, on information sharing and collaboration.

The study enabled us to understand the platform relations and the process of assimilation of tools to identify drivers of the assimilation of collaborative platforms. The successful assimilation of any information technology requires the mutual adaptation of both the technology and organizational practices. As mentioned before, the company worked seamlessly with suppliers to understand their needs, both in the technological sense as well as the organizational one. Related to the technological context, technology readiness and technology integration are positive factors for e-business assimilation. Other drivers are important for assimilating IT:

- All design suppliers integrated right from the initial phase of projects (for case I)

- Development time kept strictly in line with project milestones

- $\quad$ These tools have been specifically designed and made available by Company \#I to help its third parties understand its expectations

\section{Managerial implications}

Integrating product value chain activities and the different firms, which can provide an optimized set of competencies, is certainly one of the major challenges facing most industries in the coming decade. Although the web can act as a major facilitator, it is only a partial answer to supply chain integration. This study provides insights for managers related to the use of collaborative tools and recognizes research from Childerhouse and Towill (20II) that describes routes established for practices when seeking to improve integrative capability. Companies start with enhanced internal effectiveness, followed by upstream streamlining and then finally downstream integration. Managers need to focus on operationalizing the individual components of supply chain integration, e.g., internal, customer and supplier integration, and combine efforts to implement collaborative technologies to promote supply chain collaboration. Internal links can represent critical success factors to achieve collaboration levels that can improve performance.

\section{Limitations and Future studies}

This research analyzed only one side of the issue (focal company and global company), but it is very important to conduct an overall survey of suppliers that are using this platform. There are clear differences in the perceptions of the suppliers from those of the large companies. To prepare an analysis of the challenges and efforts, it is also important to include the perceptions of suppliers and customers; this analysis allows us to raise more deeply relational perceptions and technological issues that need to be addressed to integrate supply chains.

\section{Conclusion}

The findings have indicated that the trajectory of the integration can be achieved, but there are many challenges and required efforts. The company has invested time and money to improve integration though their portal, but this integration depends on suppliers and plants (in this case, global companies). From the examination of this case, interesting lessons are derived regarding the suitability and criticality of the technological approach used to support collaboration, especially regarding the use of a centralized web platform compared to the classical EDI approach and to a decentralized solution based on web services. Another point is related to benefits; companies have described benefits from their use of portals, but there are also many challenges, such as technological capability, user acceptance, the learning curve, the need for trust between planner and buyer, etc., to achieving these benefits. In general, the portal enabled communication, collaboration and trade between many users and geographical regions. More importantly, it joins suppliers and global partners using a single, standardized, flexible and open architecture, allowing improvements in productivity, vision and dialog, with a lower number of connections to be maintained. The transparency allowed by IT provides insights for repositioning in the chain and the means for collaboration between companies, with the purpose of optimizing their position in the business. The results of this research are limited to the specific case studies, and further validation of the research findings through qualitative and quantitative methods would be appropriate. 


\section{References}

BARRATT, M,(2004) .Understanding the meaning of collaboration in the supply chain., Supply Chain Management, 9(I), 30-42. doi: I0.1 I08/I35985404I05I7566

BARRATT, M.A. and Barratt, R., (20II) "Exploring Internal and External Supply Chain Linkages: Evidence from the field", Journal of Operations Management 29(5), 5I4-528. doi:10.1016/j.jom.2010.11.006

BARRATT, M.A., Oke, A.(2007) Antecedents of supply chain visibility in retail supply chains: a resource-based theory perspective. Journal of Operations Management 25 (6), 1217-1233. doi:10.1016/j.jom.2007.01.003

CARR, A.S., Smeltzer, L.R. (2002), "The relationship between information technology use and buyer-supplier relationships: an exploratory analysis of the buying firm's perspective", IEEE Transactions on Engineering Management, 49 (3), 293304. doi.org//0.1 109/tem.2002.803389

CASSIVI, L., Hadaya, P., Lefebvre, E., \& Lefebvre, L. A. (2008). The role of collaboration on process, relational, and product innovations in a supply chain. International Journal of e-Collaboration (IJeC), 4(4), II-32. doi:I0.40I8/ jec.2008100102

CASSIVI, L., Lefebvre, L.A., \& Le Hen, G. (2000). Supply Chain Integration in the Automobile Industry: The Case of ANX. In Proceedings at the 8 th International Conference on Management of Technology.

CASSIVI, Luc (2006) "Collaboration planning in a supply chain", Supply Chain Management: An International Journal, I I (3), 249 - 258. doi: I 0. I I08/I35985406 I0662 I 58

CHALMETA, R., Campos, C., \& Grangel, R. (200I). References architectures for enterprise integration. Journal of Systems and Software, 57(3), I75-191. doi:10.1016/s0164I2I2(0I)00008-5

CHAN, F. T., Chong, A. Y. L., \& Zhou, L. (2012). An empirical investigation of factors affecting e-collaboration diffusion in SMEs. International Journal of Production Economics, I 38(2), 329-344. doi:I0.1016/j.ijpe.2012.04.004

CHILDERHOUSE, P \& D.R.Towill (20I I):Arcs of supply chain integration, International Journal of Production Research, 49(24), 744|-7468 doi:10.1080/00207543.2010.524259
CHUNG, S. H., Tang, H. L., \& Ahmad, I. (20II). Modularity, integration and IT personnel skills factors in linking ERP to SCM systems.Journal of technology management \& innovation, 6(I), I-3. doi: I0.4067/s07/8-272420 I I000I0000 I

DANESE, P., \& Bortolotti, T. (20I4). Supply chain integration patterns and operational performance: a plant-level surveybased analysis. International Journal of Production Research, 52(23), 7062-7083. doi:10.1080/00207543.20।4.9355।5

DIDONET, S. R., \& Díaz, G. (20I2). Supply chain management practices as a support to innovation in SMEs. Journal of technology management \& innovation, 7(3), 91-109. doi:|0.4067/s07|8-272420I2000300009

FLYNN, B.B., Huo, B., Zhao, X., 20I0. The impact of supply chain integration on performance: a contingency and configuration approach. Journal of Operations Management 28 (I), 58-71. doi:I0.1016/j.jom.2009.06.00I

FORZA, C. (2002). Survey research in operations management: a process-based perspective. International Journal of Operations \& Production Management, 22 (2), I52-194. doi: I0.1108/014435702104I4310

GUNASEKARAN, A., \& Ngai, E. W. (2004). Information systems in supply chain integration and management. European Journal of Operational Research, 159 (2), 269-295. doi:10.1016/j.ejor.2003.08.016

JAYARAM, J., Vickery, S.K. (1998), "Supply-based strategies, human resource initiatives, procurement lead time, and firm performance", International Journal of Purchasing and Materials Management, 34(I), 12-23. doi:10.1 III/j.1745493x.1998.tb00038.x

JIAZHEN, X. F. H. (2004). Using Web Service to Realize Enterprise Information System Integration in Supply Chain . Computer Applications and Software, I, 019.

JOHNSON, M.E. and S. Whang, (2002).E-business and supply chain management: an overview and framework. Production and Operations management. II (4), 4I3-422. doi:10.1 I I I/j. 1937-5956.2002.tb00469.x

KAMINSKY, Philip et al. Cadeia de suprimentos: projeto e gestão. Porto Alegre, 2003. 328p.

WON LEE,C., Kwon, I.G.,\& Severance, D.(2007). Relationship between supply chain performance and degree of linkage among supplier, internal integration, and customer.Supp Chain Mnagmnt, I2(6), 444-452. doi: I 0. I I08/I 35985407 I082637 I

ISSN: 07 I 8-2724. (http://www.jotmi.org) 
LEE, C.W., I.W.G. Kwon and S Joo (2008). Severance, "Supply Chain Integration and Its Impact on Performance: A Structural Equation Model Approach North America Research/Teaching Symposium. 2008

LI, G., Yang, H., Sun, L., \& Sohal, A. S. (2009). The impact of IT implementation on supply chain integration and performance. International Journal of Production Economics, I20(I), 125138. doi:10.1016/j.jpe.2008.07.017

LI, Q.,Wang, Z.Y., Cao, Z. C., Du, R.Y., \& Luo, H. (20I4). Process and data fragmentation-oriented enterprise network integration with collaboration modelling and collaboration agents. Enterprise Information Systems, I-3 I. doi: I0.1080/I 7517575.2013 .879742

LINDQUIST,A.,Berglund,F.,\& Johannesson,H.(2008).Supplier Integration and Communication Strategies in Collaborative Platform Development. Concurrent Engineering, 16(I), 2335. doi: 10.1 I $77 / 1063293 \times 07084639$

LIU, H., Ke, W., Wei, K. K., \& Hua, Z. (20I3). The impact of IT capabilities on firm performance: The mediating roles of absorptive capacity and supply chain agility. Decision Support Systems, 54(3), I452-I462. doi:10.1016/j.dss.2012.12.016

MENTZER, J.T., DeWitt, W., Keebler, J.S., Min, S., Nix, N.W., Smith, C.D., Zacharia, Z.G., (200I). Defining supply chain management. Journal of Business Logistics 22 (2), I-24 doi:I0.1002/j.2158-I592.200I.tb0000I.x

MEYER, M.H.,Tertzakian, P.and Utterback,J.M.( (1997). Metrics for Managing Research and Development in the Context of the Product Family, JSTOR, 43(I): 88-III. doi:10.1287/ mnsc.43.1.88

MU, ENRIQUE; Kirsch, Laurie J.; Butler Brian S.(20I5) The assimilation of enterprise information system: An interpretation systems perspective, Information \& Management, Volume 52, Issue 3, April 2015, Pages 359-370, doi:10.1016/j.im.2015.01.004

MUKHOPADHYAY, T., S. Kekre.(2002). Strategic and operational benefits of electronic integration in $\mathrm{B} 2 \mathrm{~B}$ procurement processes. Management Sci. 48(I0) I30 I-I3 I3. doi:10.1287/mnsc.48.10.1301.273

PANETTO, Hervé, A. Molina, 2008. Enterprise Integration and Interoperability in Manufacturing Systems Volume 59, Issue 7, pp 64I-646. doi:10.1016/j.compind.2007.12.010
PAULRAJ, A., Chen, I. J., \& Lado, A. A. (20I2). An empirical taxonomy of supply chain management practices. Journal of Business Logistics, 33(3), 227-244. doi:10.1 I I //j.00000000.20I2.01046.x

PRAMATARI, K. Collaborative supply chain practices and evolving technological approaches (2007) Supply Chain Management, 12 (3), 210-220. doi:I0.I I08/I35985407/ 0742527

RUSSELL, D. M., and Hoag, A. M. (2004). "People and Information Technology in the Supply Chain: Social and Organizational Influences on Adoption." International Journal of Physical Distribution \& Logistics Management, Vol. 34 (I/2), I02-I23. doi: I0.I 108/096000304I05269|4

SIMPSON, T.W., Maier, J.R.A. and Mistree, F. (200I). Product Platform Design, Research Engineering Design, I3(I): 2-22. doi:10.1007/s001630100002

SODERO, A. C., Rabinovich, E., \& Sinha, R. K. (20I3). Drivers and outcomes of open-standard interorganizational information systems assimilation in high-technology supply chains. Journal of Operations Management, 3 I (6), 330-344. doi:10.1016/j.jom.2013.07.008

TAPSCOTT, D. and Ticoll, D. (2005). A Empresa Transparente - São Paulo- M. Books do Brasil Editora

TIAN-MIN, C. (2009). Constructing collaborative E-business platform to manage supply chain. In 2009 International Conference on Information Management, Innovation Management and Industrial Engineering, vol. 2, pp. 406-409. doi:I0.1 109/iciii.2009.255

VAN DER VAART, T., van Donk, D.,(2008). A critical review on survey-based research in supply chain integration. International Journal of Production Economics III (I), 4255. doi:10.1016/j.ijpe.2006.10.01 I

VARELLA, L., \& Buss Gonçalves, M. (20I3). Information Technology as the Main Competence in the Design of the Strategic Planning of Logistics Platforms. Journal of technology management \& innovation, 8(3), 160-172. doi: $10.4067 / \mathrm{s} 07 \mid 8-272420130004000 / 5$

VICKERY, S. K., Jayaram, J., Droge, C., \& Calantone, R. (2003). The effects of an integrative supply chain strategy on customer service and financial performance: an analysis of direct versus indirect relationships. Journal of operations management, 2 I (5), 523-539. doi: I0.10 I6/j.jom.2003.02.002 
VICKY MANTHOU, Maro Vlachopoulou, Dimitris Folinas,(2004) Virtual e-Chain (VeC) model for supply chain collaboration, International Journal of Production Economics, 87(3), 24I-250. doi:10.1016/s0925-5273(03)002 I8-4

VOSS, C., Tsikriktsis, N., \& Frohlich, M. 2002. Case research in operations management. International Journal of Operations \& Production Management, 22(2), 195-219. doi:I0.1 I08/014435702104|4329

VREEDE, G-Jan; Dickson, Gary.(2000) "Using GSS to Design Process and Information Systems". Group Decision and Negotiation, ABI / INFORM Global, doi: doi:10.1007/10726.1572-9907

WU, L., Chuang, C. H., \& Hsu, C. H. (20I4). Information sharing and collaborative behaviors in enabling supply chain performance: A social exchange perspective. International Journal of Production Economics, I48, I22- I32. doi: 10.10 I6/j. ijpe.2013.09.016

YU, L., Suojapelto, K., Hallikas, J., \& Tang, O. (2008). Chinese ICT industry from supply chain perspective-A case study of the major Chinese ICT players. International Journal of Production Economics, II5(2), 374-387. doi:10.1016/j. ijpe.2008.03.0II

ZHAO, X., Huo, B., Selen, W., \& Yeung, J. H. Y. (20II). The impact of internal integration and relationship commitment on external integration. Journal of Operations Management, 29(I), 17-32. doi:I0.1016/j.jom.2010.04.004

ZHOU, H., \& Benton, W. C. (2007). Supply chain practice and information sharing. Journal of Operations management, 25(6), 1348-1365. doi:10.1016/j.jom.2007.01.009 